\title{
A Resource Allocation Modelfor Tiger Habitat Protection
}

\author{
Susmita Dasgupta ${ }^{1}$, Dan Hammer ${ }^{2}$, Robin $\mathrm{Kraft}^{3} \&$ David Wheeler ${ }^{4}$ \\ ${ }^{1}$ Development Research Group, World Bank \\ ${ }^{2}$ Department of Agricultural and Resource Economics, University of California, Berkeley \\ ${ }^{3}$ World Resources Institute \\ ${ }^{4}$ Center for Global Development \\ Correspondence: Susmita Dasgupta. Development Research Group, MSN: MC-3-308, The World Bank. 1800 H \\ Street, Washington DC 20433, USA. Tel: 1-202-473-2679. E-mail: sdasgupta@worldbank.org
}

Received: April 21, $2014 \quad$ Accepted: June 1, 2014 Online Published: August 29, 2014

doi:10.5539/jms.v4n3p16 URL: http://dx.doi.org/10.5539/jms.v4n3p16

\begin{abstract}
Conservation of habitats is critical for survival of endangered tigers. This paper develops a resource allocation model for tiger habitat protection incorporating information about threats to particular tiger subspecies, the quality of remaining habitat areas, the observed effectiveness of habitat protection by country, and the potential costs of protection projects for 74 habitats in Asia. Implementation of the model moves through two stages. The first stage employs user-specified weights to combine numerous subindices into composite indices of species threat, habitat quality, potential project costs and protection effectiveness. The second stage employs additional user-specified weights to combine the composite indices into priority scores and potential project budget shares for all 74 habitat areas.

Exploration of model results suggests that changes in user-specified weights can have very significant consequences for habitat priority scores. Illustrative scenarios indicate that no single priority ordering can be prescribed in such a diverse setting, and actual priorities will depend on the preferences of decision-makers, as revealed in the weights assigned to species threats, habitat quality, cost elements, and effective protection. At the same time, the model can make a useful contribution by identifying priority orderings that are consistent with different sets of preferences. And it can inform policy discussions by allowing for extended exploration of alternative strategies, along with providing feedback to decision makers about the implicit preferences associated with their resource allocation decisions.
\end{abstract}

Keywords: biodiversity conservation, tiger habitat, resource allocation

\section{Introduction}

The International Union for Conservation of Nature has classified the tiger as endangered in its Red list of Threatened Species of (http://www.iucnredlist.org/details/15955/0). The wild tiger population of tropical Asia dropped from about 100,000 to 3,500 in the past century. The Bali, Javan and South China subspecies are believed to be extinct in the wild. An estimated 2,380 Bengal tigers survive, along with 340 Indochinese, 500 Malayan and 325 Sumatran tigers. The surviving wild tiger population of tropical Asia inhabits a scattered arc from southwest India to northwest Indonesia, much of it in upland areas. Bengal tigers survive in India, Nepal, Bhutan, Bangladesh and northern Myanmar, while the remaining Indochinese tigers are found in western and southeastern Myanmar, Lao PDR, Vietnam, Cambodia and Thailand. In contrasting geographic concentration, Sumatran tigers are confined to one Indonesian island and Malayan tigers exist only in Peninsular Malaysia and one small area in southern Thailand. Long term survival of the tiger is dependent on conservation of tiger habitats.

The global community has mobilized to conserve the tiger's remaining habitat through the Global Tiger Initiative, which is supported by all countries with known tiger populations, the World Bank, and over 40 civil society organizations. Participating countries and institutions have endorsed the Global Tiger Recovery Program (GTRP), which aims to double the number of wild tigers by 2022 through habitat conservation programs and cooperation across national boundaries to stop poaching and illegal trade in tiger parts.

Operating under tight budget constraints, the GTRP confronts several complicating factors, including the need to 
conserve specific habitats large enough to accommodate this keystone predator; differential threats to important regional subspecies that must be preserved (Bengal, Indochinese, Malayan and Sumatran tigers); divided national jurisdictions; differences in countries' institutional capabilities, conservation management costs, and willingness to pay for conservation; and, not least, widely-differing and rapidly-changing opportunities for commercial exploitation of remaining habitat areas.

Cost-effective resource allocation under these dynamic conditions involves frequent reassessment of threats and opportunities in many habitat areas scattered across the tiger range countries. Timely analysis requires near-real-time forest monitoring information, which is now available from FORMA (Forest Monitoring for Action), a new database developed by a research consortium that includes the Center for Global Development (http://www.cgdev.org/forma), the World Resources Institute, the University of Maryland, and Resources for the Future, in consultation with World Bank staff, Conservation International, the Nature Conservancy and WWF. Drawing on data from NASA's MODIS system, FORMA provides monthly updates on forest clearing at high spatial resolution for tropical Asian countries with tiger habitat.

From a formal analytical perspective, saving the tiger involves optimal spatial resource allocation with a limited budget, a short time horizon (to prevent extinction), a complex, constantly-changing spatial distribution of potential conservation benefits and costs, and the prospect of rapid, irreversible losses in areas where conservation is weak. Combining the FORMA information with a spatially-disaggregated database of economic, demographic and geographic information, previous papers by the authors have focused on identifying area-specific drivers of habitat destruction (Dasgupta et al., 2012a), and testing the effects of interventions intended to protect habitat (Dasgupta et al., 2012b).

In this paper, we draw on information and insights from the previous papers to develop a model that can inform the allocation of GTRP resources for tiger habitat conservation. Designed for frequent updates as new information becomes available, the model estimates priorities and potential program budget shares for 74 tiger habitat areas in 9 countries: Cambodia, India, Indonesia, Lao PDR, Myanmar, Malaysia, Nepal, Thailand and Vietnam. It incorporates four key factors for resource allocation: differential threats to tiger subspecies, habitat quality, potential project implementation costs, and recent evidence on the effectiveness of countries' protection policies.

\section{Method}

\subsection{Theoretical Framework}

To provide a consistent modeling framework, we adopt an approach to optimal allocation that draws on prior theoretical and empirical work by Behrman, Pollak and Taubman (1982), Bolt et al. (2003), Buys et al. (2004), Pandey et al. (2005) and Wheeler (2011). In this model, the welfare impact of conservation project expenditures is a function of their levels and distributions across tiger habitat areas. Resource allocation decisions by the Global Tiger Recovery Program must incorporate and balance three factors: tiger subspecies preservation; representation for all participating countries; and overall welfare maximization. We cannot realistically characterize the program's objective function as linear (infinite elasticity of substitution across habitat areas), because sole allocation to one area is infeasible, whatever the relative scale of its protection problem. Broader geographic coverage is implied by the program's charter. At the same time, the objective function is not purely fixed-coefficient (zero elasticity of substitution across areas), because nothing forces it to maintain cross-country parity in allocation. This is good, since the distribution of habitat protection problems is likely to be far from even across areas.

We adopt an intermediate assumption: that the objective function is characterized by unit-elastic substitution across areas. A unit-elastic (Cobb-Douglas) welfare function permits tailoring of programs to area-specific conditions, while encouraging portfolio diversification through the operation of diminishing returns. Expected welfare gains from expenditures are related to both the scale of habitat protection problems and the cost of successful protection under local conditions.

Formally, we specify the resource allocation problem as follows:

$$
\text { Welfare Function: } W=\prod_{i j k} T_{i j k}^{\rho_{i}}
$$

where $T_{i j k}=$ Expected number of surviving tigers of subspecies $\mathrm{i}$ in habitat $\mathrm{j}$, country $\mathrm{k}$

$\rho_{\mathrm{i}} \quad=$ Exogenous extinction risk for tigers of subspecies $\mathrm{i}$.

Extinction risk is a function of overall deterioration of the subspecies' habitat in the region (D), the number of surviving tigers in the subspecies $(\mathrm{T})$, and the number of countries $(\mathrm{N})$ that still harbor them: 


$$
\rho_{i}=\gamma_{0} D_{i}^{\gamma_{1}} T_{i}^{\gamma_{2}} N_{i}^{\gamma_{3}}
$$

The expected number of surviving tigers is a function of habitat quality and the effectiveness of habit protection in country $\mathrm{k}$.

$$
T_{i j k}=\alpha_{0} G_{j k}^{\alpha_{1} Q_{j k}^{\alpha_{1}} P_{k}^{\alpha_{2}}}
$$

where $\mathrm{G}_{\mathrm{jk}}=$ Scale of GTRP activity in habitat $\mathrm{j}$, country $\mathrm{k}$

$\mathrm{Q}_{\mathrm{jk}}=$ Quality of habitat $\mathrm{j}$, country $\mathrm{k}$

$\mathrm{P}_{\mathrm{k}}=$ Effectiveness of habitat protection in country $\mathrm{k}$

Habitat quality is a function of habitat size $(\mathrm{H})$ and fragmentation $(\mathrm{F})$ :

$$
Q_{j k}=\delta_{0} H_{j k}^{\delta_{1}} F_{j k}^{\delta_{2}}
$$

Resource allocation is limited by an overall budget constraint:

$$
\bar{B}=\sum_{j k} C_{j k} G_{j k}
$$

where $\mathrm{B}=$ Available budget

$\mathrm{C}_{\mathrm{jk}}=$ Unit cost of protection for habitat $\mathrm{jk}$

Unit protection costs reflect a combination of economic incentives for local conservation and the direct cost of habitat protection, which is principally a function of local labor cost.

$$
\mathrm{C}_{\mathrm{jk}}=\beta_{0} L_{j k}^{\beta_{1}} W_{k}^{\beta_{2}}
$$

where $\quad \mathrm{L}=$ Opportunity cost of land in habitat $\mathrm{jk}$

$\mathrm{W}=$ Labor cost in country $\mathrm{k}$

Substituting (3) into (1) yields the following welfare function:

$$
W=\prod_{i j k} G_{j k}^{\alpha_{1} Q_{j k}^{\alpha_{1}} P_{k}^{\alpha_{2}}}
$$

Maximization of $\mathrm{W}$ subject to the overall budget constraint yields the following ratio of optimal GTRP resource allocations for protection of arbitrarily-chosen habitat areas 1 and 2 with tiger subspecies $\mathrm{m}$ and $\mathrm{n}$ :

$$
\frac{C_{1} G_{1}^{*}}{C_{2} G_{2}^{*}}=\frac{\rho_{m}^{\alpha_{1}} Q_{1}^{\alpha_{2}} P_{1}^{\alpha_{3}}}{\rho_{n}^{\alpha_{1}} Q_{2}^{\alpha_{2}} P_{2}^{\alpha_{3}}}
$$

Substituting and re-arranging, we obtain:

$$
\frac{G_{1}^{*}}{G_{2}^{*}}=\frac{\hat{\rho}_{m}^{\alpha_{1}} \hat{Q}_{1}^{\alpha_{2}} P_{1}^{\alpha_{3}} \hat{C}_{1}^{\alpha_{4}}}{\hat{\rho}_{n}^{\alpha_{1}} \hat{Q}_{2}^{\alpha_{2}} P_{2}^{\alpha_{3}} \hat{C}_{2}^{\alpha_{4}}}
$$

The program priority score of habitat area 1 is the numerator of (9), where $\hat{\rho}, \hat{Q}$ and $\hat{C}$ are calculated from (2), (4) and (6), respectively. Its share of the program budget is

$$
s_{1}=\frac{S_{1}}{\sum_{j=1}^{N} S_{j}}
$$

\subsection{Quantifying Habitat Protection Factors}

To implement the model, we quantify the allocation factors using the database developed in Dasgupta et al. (2012a). For each tiger habitat area, we develop composite measures as follows. Variables are denoted by letters 
from the previous equations.

(1) Subspecies extinction risk ( $\rho$ ). Our measure has three components:

a. Species numbers $(\mathrm{T})$ : Table 1 provides recent estimates of surviving tiger populations, by subspecies and country. Our measure for each subspecies is its share of the total tiger population.

b. Overall habitat loss (D): For each habitat area, we compute natural forest cover remaining by August, 2011. This combines measures from Hansen, et al. (2006) for 2000, Hansen, et al. (2008) for $2000-2005$, and FORMA data for January, 2006 to August, 2011. Across all areas, we total original and remaining forest cover by subspecies, and compute the overall percentage of original forest that has been subject to clearing.

c. Species distribution across countries $(\mathrm{N})$ : In standard portfolio terms, spreading the remaining tigers across polities should reduce aggregate risk. Our index of "portfolio risk" is the intercountry entropy measure (E) for each subspecies, where

$$
E_{i}=-\sum_{k=1}^{K} s_{i k} \ln s_{i k}
$$

ands $s_{k}=$ Country k's share of surviving tigers of subspecies i.

Table 1. Surviving wild tiger population*

\begin{tabular}{lrlrllll}
\hline Bengal $^{\text {a }}$ & & Indochinese & & Malayan & \multicolumn{3}{c}{ Sumatran } \\
\hline India & 1,706 & Thailand & 200 & Malaysia & 500 & Indonesia & 325 \\
Bangladesh & 440 & Myanmar & 85 & (Peninsular) & & (Sumatra) & \\
Nepal & 155 & Vietnam & 20 & & & & \\
Bhutan & 75 & Cambodia & 20 & & & & \\
& & Lao PDR & 17 & & & & \\
Total & 2,376 & & 342 & & 500 & & 325 \\
\hline
\end{tabular}

Note. ${ }^{*}$ Midrange estimates ${ }^{\text {a }}$ No current estimate for Myanmar

Source: Dasgupta et al. (2012a).

(2) Habitat Quality (Q). This includes two components: Habitat area $(\mathrm{H})$ and the degree of fragmentation (F). For the latter, we use the percentage of habitat area not subject to clearing by August, 2011.

(3) Effectiveness of protection (P): For all tiger habitat areas within a country, we total original and remaining forest area and compute the shares of original forest that were subjected to clearing by 2000 and August, 2011, respectively. The increase in share from 2000 to 2011 is a proxy for the risk of protection failure during the period.

(4) Protection project Cost (C). This includes two components:

a. Habitat land opportunity cost (L): In Dasgupta, et al. (2012a), we specify a model that relates local forest clearing to the profitability of alternative uses for the land. By implication, the best single measure of the opportunity cost of forested land in a locality is the intensity of recent clearing. Accordingly, our proxy for opportunity cost in each habitat is the increase in the percent of its area cleared from 2000 to August, 2011.

b. Labor cost $(\mathrm{W})$ : We incorporate relative protection project costs using differential wages, with income per capita as the proxy and an exponential weight (0.6) that reflects the findings of Harrison (2002) on the labor share of income in low- and middle-income countries.

\subsection{Model Implementation}

We transform all model variables to ranks for ease of use and interpretation, and to ensure robustness against outlier effects. We report the raw variable values in Appendix A. To facilitate the nested procedure that we describe below, our rank-ordering for each variable ensures a positive relationship to the priority scores in (9). Accordingly, higher numerical ranks are assigned to lower values for subspecies numbers $(\mathrm{T})$, subspecies distribution (E), land opportunity cost (L) and labor cost (W). Higher numerical ranks are assigned to higher values for subspecies' overall habitat loss (D), habitat area $(H)$, the percent of habitat remaining $(\mathrm{F})$, and the effectiveness of country protection $(\mathrm{P})$.

Our model incorporates equations (1) - (10) in a two-stage exercise. In the first stage, the user specifies relative 
weights for the determinants of $\rho, \mathrm{Q}$ and $\mathrm{C}$ in (2), (4) and (6) above.The model allows the user to specify the parameters for each equation in arbitrary units. After the parameters are specified, the model standardizes to Cobb-Douglas (CD) parameters by dividing each parameter by the sum of parameters for that equation. Then it forms the product of the relevant rank-transformed variables, each weighted by its exponential CD parameter.

At the completion of the first stage, the model has created indices for $\rho, Q$ and C. P (protection effectiveness) has only one component, so that is the second-stage index for this variable. At the beginning of the second stage, the user specifies relative weights for species risk $(\rho)$, habitat quality $(\mathrm{Q})$, protection effectiveness $(P)$ and project cost (C). As before, the model allows the user to specify the weighting parameters in arbitrary units. Then it standardizes to CD parameters and forms the product of the four indices, each weighted by its exponential CD parameter.

The most critical question for our modeling exercise relates to the potential variation in outcomes for different user settings of model parameters. To address this question, Table 2 provides rank correlations for the 8 variables incorporated in the model. The results are almost evenly divided between positive and negative correlations; some are strong but most are relatively weak. Overall, these results indicate that the habitat priorities and implicit budget shares calculated by the model are highly dependent on user-specified weights.

Table 2. Rank correlations for model variables

\begin{tabular}{|c|c|c|c|c|c|c|c|}
\hline Obs $=74$ & $\begin{array}{l}\text { Subspecies } \\
\text { Numbers }\end{array}$ & $\begin{array}{l}\text { Subspecies } \\
\text { Distribution }\end{array}$ & $\begin{array}{l}\text { Subspecies } \\
\text { Habitat } \\
\text { Threat }\end{array}$ & $\begin{array}{l}\text { Habitat } \\
\text { Size }\end{array}$ & $\begin{array}{l}\text { Habitat } \\
\text { Percent } \\
\text { Remaining }\end{array}$ & $\begin{array}{l}\text { Habitat } \\
\text { Land Opp. } \\
\text { Cost }\end{array}$ & $\begin{array}{l}\text { Habitat } \\
\text { Labor } \\
\text { Cost } \\
\end{array}$ \\
\hline Subspecies Numbers & 1.00 & & & & & & \\
\hline Subspecies Distribution & 0.06 & 1.00 & & & & & \\
\hline Subspecies Habitat Threat & -0.75 & -0.43 & 1.00 & & & & \\
\hline Habitat Size & 0.22 & -0.18 & -0.21 & 1.00 & & & \\
\hline Habitat Percent Remaining & 0.41 & 0.20 & -0.46 & 0.16 & 1.00 & & \\
\hline Habitat Land Opp. Cost & -0.57 & -0.13 & 0.62 & -0.43 & -0.30 & 1.00 & \\
\hline Habitat Labor Cost & -0.28 & -0.35 & 0.51 & 0.13 & -0.03 & 0.16 & 1.00 \\
\hline $\begin{array}{l}\text { Country Protection } \\
\text { Effectiveness }\end{array}$ & -0.78 & -0.44 & 0.87 & -0.23 & -0.43 & 0.66 & 0.41 \\
\hline
\end{tabular}

\section{Results}

To illustrate the possible range of variation, we implement the model for three sets of parameter weights. The first two give extra weight to subspecies threats and project cost elements, while the third assigns equal weight to all variables.

The subspecies threat scenario assigns unit weights to first-stage variables except for subspecies numbers $(\mathrm{T})$ and distributions across countries $(\mathrm{N})$, which are assigned weights of 5. In the second stage, we assign a weight of 3 to subspecies threat and unit weights to the other three indices. The cost scenario assigns a weight of 3 to the cost index in the second stage, leaving all other weights at unit values. The equal-weights scenario assigns unit weights to all variables in both stages.

Table 3 shows that these weighting changes have very significant consequences for the priority rankings of the 74 tiger habitat areas in the model: The rank correlations of Species Threat with Cost and Equal Weights are .41 and .64 respectively, while the correlation between Equal Weights and Cost is .82 .

Table 3. Habitat rank correlations

\begin{tabular}{lcc}
\hline & Species Threat & Cost \\
\hline Species Threat & 1.00 & \\
Cost & 0.41 & 1.00 \\
Equal Weights & 0.64 & 0.82 \\
\hline
\end{tabular}

Table 4 presents results for all 74 habitat areas, sorted by rank in the Species Threat Scenario. Inspection of the top entries indicates that the major beneficiaries of extra weighting for species threat are habitat areas in Indonesian Sumatra, the sole locale of the Sumatran tiger, which rank much higher than in the Cost and Equal 
Weighting scenarios. This applies particularly to Bukit Balai Rejang-Selatan and Gunug Leuser, which move to first and second in the priority ordering. Subspecies scores for the critically-threatened Indochinese Tiger are also high, which produces high ranks for several Vietnamese, Laotian and Thai habitat areas (e.g., Northern and Southern Annamites, Phu Miang - Phu Thong, Taman Negara-Belum).

The Cost scenario shifts habitat scores toward areas that have low labor costs, low land opportunity cost indices, or both. As a result, the highest priorities are assigned to some habitat areas in Nepal (Corbett-Sonanadi, Royal Bardia, Royal Chitwan, Royal Suklaphanta), Myanmar (Northern Forest Complex - Namdapha - Royal Manas), and India (Dandeli - Anshi, Royal Chitwan, Kanha û Phen, Western Ghats: Bandipur - Khudrenukh û Bhadra, Simlipal, Kaziranga - Garampani). At the same time, cost advantages in Vietnam and Lao PDR maintain high rankings for several areas with high priorities in the Species Threat scenario (particularly the Northern and Southern Annamites). The Equal Weights scenario favors many of the same protected areas in Nepal, Vietnam, Lao PDR and India.

\section{Discussion}

The three illustrative cases suggest that the priority rankings of some habitat areas are highly sensitive to variable weighting, while others are not. However, these are only three of many possible scenarios, and the correlations in Table 2 suggest that most habitat areas would change priority ordering substantially for some values of the 8 weighting parameters.

To clarify the aggregative implications of our results, Tables 5(a)-(c) present summaries at the country level for Species Threat, Cost and Equal Weights. The tables reproduce the country-level ranks for Subspecies Numbers, Subspecies Distribution, Subspecies Habitat, Labor Cost and Effective Protection. The ranks for Habitat Size, Habitat Percent and Land Cost are determined from mean values for habitat-level data. The scores for the three criterion variables (Species Threat, Cost, Equal Weights) are means of habitat-level scores.

In Table 5(a) the high Species Threat rankings for Lao PDR, Vietnam and Indonesia are consistent with the previously-noted high rankings for several Tiger Landscapes in Table 4. Similarly, the Cost and Equal Weight summaries in Tables 5(b) and 5(c) confirm the previously-noted advantages of Tiger Landscapes in Nepal, Lao PDR, Vietnam and India.

We conclude that the principal value of our modeling system is educational rather than prescriptive. Undertaking numerous weighting experiments can provide a useful sense of the relationship between decision-makers' preferences and habitat assistance priorities. In the same vein, the model can be used to reveal the preferences of decision-makers who have assigned priorities to different habitats in resource allocation.

\section{Summary and Conclusions}

In this paper, we have developed and implemented a model that translates detailed information about 74 tiger habitat areas into consistently-derived priority scores and potential project budget shares for those areas. Drawing on the database constructed by Dasgupta, et al. (2012a), the model incorporates information about threats to particular tiger subspecies, the quality of remaining habitat areas, the observed effectiveness of habitat protection by country, and the potential costs of protection projects for different habitats. Implementation of the model moves through two stages. In the first, user-specified weights are employed to combine sub-indices into composite indices of species threat, habitat quality, cost and protection effectiveness. In the second stage, user-specified weights are employed to combine the composite indices into priority scores and potential project budget shares for all 74 habitat areas.

Our investigation of inter-variable correlations suggests that changes in user-specified weights can have very significant consequences for habitat priority scores. In three illustrative scenarios, we investigate the implications of equal weights for all model variables, higher weights for species threats, and higher weights for potential project costs. We find very substantial differences in high-priority habitats across the three scenarios, although habitats in some countries retain high positions in all three.

In summary, we find that great habitat diversity is revealed by the introduction of eight critical variables for priority-setting. No single priority ordering can be prescribed in such a diverse setting, and actual priorities will depend on the preferences of decision-makers, as revealed in the weights assigned to species threats, habitat quality, cost elements, and effective protection. At the same time, we believe that our model can make a useful contribution by identifying priority orderings that are consistent with different sets of preferences. And it can inform policy discussions by allowing for extended exploration of alternative strategies, along with feedback to decision makers about the implicit preferences associated with their resource allocation decisions. 
Table 4. Results for three weighting scenarios

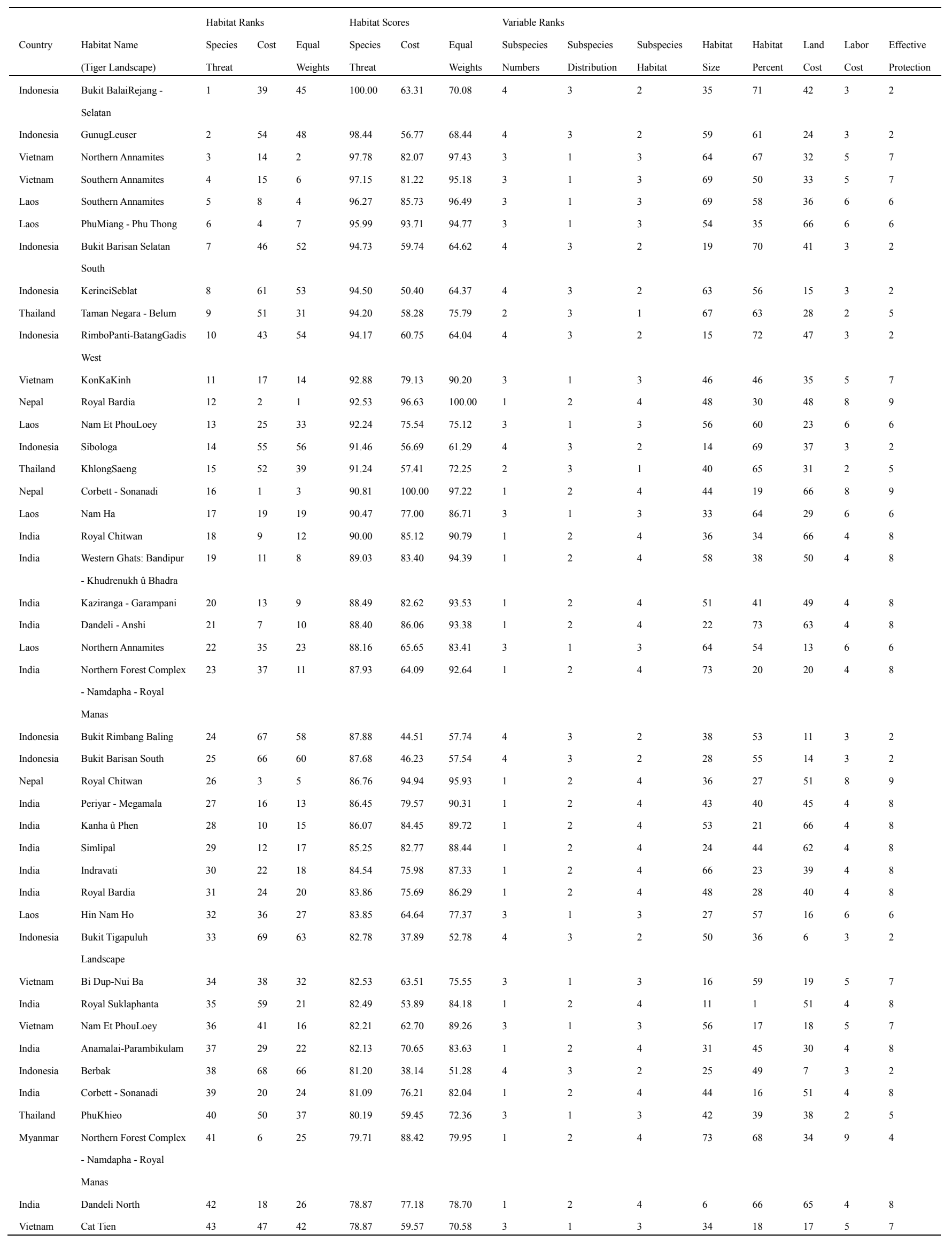




\begin{tabular}{|c|c|c|c|c|c|c|c|c|c|c|c|c|c|c|c|}
\hline Cambodia & Cardamom's & 44 & 56 & 51 & 78.67 & 54.97 & 67.43 & 3 & 1 & 3 & 60 & 52 & 9 & 7 & 3 \\
\hline India & Rajaji Minor & 45 & 21 & 28 & 77.58 & 76.11 & 76.77 & 1 & 2 & 4 & 10 & 32 & 66 & 4 & 8 \\
\hline \multirow[t]{2}{*}{ India } & Pachmarhi - Satpura - & 46 & 26 & 29 & 77.52 & 72.85 & 76.68 & 1 & 2 & 4 & 41 & 10 & 51 & 4 & 8 \\
\hline & Bori & & & & & & & & & & & & & & \\
\hline India & Radhanagari & 47 & 27 & 30 & 77.45 & 71.55 & 76.58 & 1 & 2 & 4 & 30 & 15 & 46 & 4 & 8 \\
\hline Thailand & PhuMiang - Phu Thong & 48 & 60 & 49 & 76.76 & 51.96 & 67.77 & 3 & 1 & 3 & 54 & 31 & 22 & 2 & 5 \\
\hline Myanmar & Tenasserims & 49 & 45 & 34 & 76.57 & 59.98 & 74.33 & 1 & 2 & 4 & 71 & 51 & 8 & 9 & 4 \\
\hline Thailand & Cardamom's & 50 & 57 & 44 & 76.50 & 54.40 & 70.32 & 3 & 1 & 3 & 60 & 33 & 25 & 2 & 5 \\
\hline Thailand & Tenasserims & 51 & 65 & 50 & 75.92 & 46.85 & 67.52 & 3 & 1 & 3 & 71 & 42 & 12 & 2 & 5 \\
\hline India & Pench & 52 & 28 & 35 & 75.91 & 71.34 & 74.31 & 1 & 2 & 4 & 29 & 11 & 51 & 4 & 8 \\
\hline India & Satkosia-Gorge & 53 & 44 & 36 & 74.81 & 60.64 & 72.70 & 1 & 2 & 4 & 26 & 25 & 21 & 4 & 8 \\
\hline India & Palamau & 54 & 31 & 38 & 74.53 & 70.05 & 72.30 & 1 & 2 & 4 & 32 & 8 & 51 & 4 & 8 \\
\hline \multirow[t]{2}{*}{ Indonesia } & Kualar & 55 & 70 & 70 & 74.43 & 28.37 & 45.00 & 4 & 3 & 2 & 52 & 29 & 2 & 3 & 2 \\
\hline & Kampar-Kerumutan & & & & & & & & & & & & & & \\
\hline Nepal & Royal Bardia South & 56 & 23 & 40 & 74.00 & 75.87 & 71.52 & 1 & 2 & 4 & 5 & 22 & 43 & 8 & 9 \\
\hline India & Shendurney & 57 & 42 & 41 & 73.63 & 61.85 & 70.99 & 1 & 2 & 4 & 7 & 62 & 26 & 4 & 8 \\
\hline India & Chandoli & 58 & 33 & 43 & 73.18 & 67.10 & 70.33 & 1 & 2 & 4 & 17 & 14 & 44 & 4 & 8 \\
\hline India & Sunabeda-Udanti & 59 & 32 & 46 & 72.67 & 68.30 & 69.60 & 1 & 2 & 4 & 21 & 9 & 51 & 4 & 8 \\
\hline \multirow[t]{2}{*}{ India } & Western Ghats - & 60 & 30 & 47 & 72.39 & 70.47 & 69.20 & 1 & 2 & 4 & 2 & 73 & 63 & 4 & 8 \\
\hline & Sharavathi Valley & & & & & & & & & & & & & & \\
\hline Thailand & KhaoYai & 61 & 53 & 59 & 68.90 & 56.83 & 57.63 & 3 & 1 & 3 & 20 & 7 & 72 & 2 & 5 \\
\hline Thailand & Salak-Phra & 62 & 62 & 62 & 67.58 & 47.33 & 55.98 & 3 & 1 & 3 & 8 & 37 & 27 & 2 & 5 \\
\hline India & Bandhavgarh - Panpatha & 63 & 40 & 55 & 67.06 & 63.02 & 61.69 & 1 & 2 & 4 & 18 & 4 & 51 & 4 & 8 \\
\hline India & Purna & 64 & 34 & 57 & 66.36 & 66.06 & 60.74 & 1 & 2 & 4 & 9 & 5 & 72 & 4 & 8 \\
\hline Indonesia & TessoNilo Landscape & 65 & 72 & 71 & 65.04 & 22.09 & 36.76 & 4 & 3 & 2 & 23 & 26 & 1 & 3 & 2 \\
\hline \multirow[t]{2}{*}{ Cambodia } & Cambodian Northern & 66 & 63 & 64 & 64.64 & 47.28 & 52.37 & 3 & 1 & 3 & 62 & 6 & 10 & 7 & 3 \\
\hline & Plains & & & & & & & & & & & & & & \\
\hline India & Rajaji Major & 67 & 49 & 61 & 63.29 & 59.48 & 56.57 & 1 & 2 & 4 & 3 & 12 & 51 & 4 & 8 \\
\hline Thailand & ThapLan - Pang Sida & 68 & 64 & 69 & 60.19 & 46.87 & 47.05 & 3 & 1 & 3 & 39 & 1 & 51 & 2 & 5 \\
\hline India & Biligiri Range & 69 & 48 & 65 & 59.84 & 59.56 & 52.00 & 1 & 2 & 4 & 1 & 13 & 72 & 4 & 8 \\
\hline \multirow[t]{2}{*}{ India } & Mahabaleshwar & 70 & 58 & 67 & 57.76 & 54.28 & 49.31 & 1 & 2 & 4 & 4 & 3 & 51 & 4 & 8 \\
\hline & Landscape - South & & & & & & & & & & & & & & \\
\hline Nepal & Royal Suklaphanta & 71 & 5 & 68 & 57.34 & 90.84 & 48.78 & 1 & 2 & 4 & 11 & 24 & 66 & 8 & 9 \\
\hline Malaysia & Taman Negara - Belum & 72 & 71 & 72 & 56.42 & 22.48 & 35.13 & 2 & 3 & 1 & 67 & 47 & 4 & 1 & 1 \\
\hline Malaysia & Endau Rompin & 73 & 74 & 73 & 53.09 & 20.16 & 32.06 & 2 & 3 & 1 & 47 & 43 & 3 & 1 & 1 \\
\hline Malaysia & Krau & 74 & 73 & 74 & 50.23 & 20.77 & 29.51 & 2 & 3 & 1 & 13 & 48 & 5 & 1 & 1 \\
\hline
\end{tabular}

Table 5. Summary results for countries

(a) Species Threat

\begin{tabular}{lllllllllll}
\hline Country & Rank & $\begin{array}{l}\text { Species } \\
\text { Threat }\end{array}$ & $\begin{array}{l}\text { Subspecies } \\
\text { Numbers }\end{array}$ & $\begin{array}{l}\text { Subspecies } \\
\text { Distribution }\end{array}$ & $\begin{array}{l}\text { Subspecies } \\
\text { Habitat }\end{array}$ & $\begin{array}{l}\text { Habitat } \\
\text { Size }\end{array}$ & $\begin{array}{l}\text { Habitat } \\
\text { Percent }\end{array}$ & $\begin{array}{l}\text { Land } \\
\text { Cost }\end{array}$ & $\begin{array}{l}\text { Labor } \\
\text { Cost }\end{array}$ & $\begin{array}{l}\text { Effective } \\
\text { Protection }\end{array}$ \\
\hline Laos & 1 & 91.16 & 3 & 1 & 3 & 7 & 8 & 6 & 6 & 6 \\
Vietnam & 2 & 88.57 & 3 & 1 & 3 & 6 & 5 & 5 & 5 & 7 \\
Indonesia & 3 & 87.69 & 4 & 3 & 2 & 3 & 7 & 3 & 3 & 2 \\
Nepal & 4 & 80.29 & 1 & 2 & 4 & 2 & 1 & 9 & 8 & 9 \\
Myanmar & 5 & 78.14 & 1 & 2 & 4 & 9 & 9 & 4 & 9 & 4 \\
India & 6 & 77.88 & 1 & 2 & 4 & 1 & 2 & 8 & 4 & 8 \\
Thailand & 7 & 76.83 & 2 & 3 & 1 & 5 & 4 & 7 & 2 & 5 \\
Cambodia & 8 & 71.66 & 3 & 1 & 3 & 8 & 3 & 2 & 7 & 3 \\
Malaysia & 9 & 53.24 & 2 & 3 & 1 & 4 & 6 & 1 & 1 & 1 \\
\hline
\end{tabular}


(b) Cost

\begin{tabular}{lllllllllll}
\hline Country & Rank & $\begin{array}{l}\text { Species } \\
\text { Threat }\end{array}$ & $\begin{array}{l}\text { Subspecies } \\
\text { Numbers }\end{array}$ & $\begin{array}{l}\text { Subspecies } \\
\text { Distribution }\end{array}$ & $\begin{array}{l}\text { Subspecies } \\
\text { Habitat }\end{array}$ & $\begin{array}{l}\text { Habitat } \\
\text { Size }\end{array}$ & $\begin{array}{l}\text { Habitat } \\
\text { Percent }\end{array}$ & $\begin{array}{l}\text { Land } \\
\text { Cost }\end{array}$ & $\begin{array}{l}\text { Labor } \\
\text { Cost }\end{array}$ & $\begin{array}{l}\text { Effective } \\
\text { Protection }\end{array}$ \\
\hline Laos & 1 & 91.66 & 1 & 2 & 4 & 2 & 1 & 9 & 8 & 9 \\
Vietnam & 2 & 77.04 & 3 & 1 & 3 & 7 & 8 & 6 & 6 & 6 \\
Indonesia & 3 & 74.2 & 1 & 2 & 4 & 9 & 9 & 4 & 9 & 4 \\
Nepal & 4 & 71.39 & 1 & 2 & 4 & 1 & 2 & 8 & 4 & 8 \\
Myanmar & 5 & 71.37 & 3 & 1 & 3 & 6 & 5 & 5 & 5 & 7 \\
India & 6 & 53.26 & 2 & 3 & 1 & 5 & 4 & 7 & 2 & 5 \\
Thailand & 7 & 51.12 & 3 & 1 & 3 & 8 & 3 & 2 & 7 & 3 \\
Cambodia & 8 & 47.07 & 4 & 3 & 2 & 3 & 7 & 3 & 3 & 2 \\
Malaysia & 9 & 21.14 & 2 & 3 & 1 & 4 & 6 & 1 & 1 & 1 \\
\hline
\end{tabular}

(c) Equal Weights

\begin{tabular}{|c|c|c|c|c|c|c|c|c|c|c|}
\hline Country & Rank & $\begin{array}{l}\text { Species } \\
\text { Threat }\end{array}$ & $\begin{array}{l}\text { Subspecies } \\
\text { Numbers }\end{array}$ & $\begin{array}{l}\text { Subspecies } \\
\text { Distribution }\end{array}$ & $\begin{array}{l}\text { Subspecies } \\
\text { Habitat }\end{array}$ & $\begin{array}{l}\text { Habitat } \\
\text { Size }\end{array}$ & $\begin{array}{l}\text { Habitat } \\
\text { Percent }\end{array}$ & $\begin{array}{l}\text { Land } \\
\text { Cost }\end{array}$ & $\begin{array}{l}\text { Labor } \\
\text { Cost }\end{array}$ & $\begin{array}{l}\text { Effective } \\
\text { Protection }\end{array}$ \\
\hline Laos & 1 & 86.37 & 3 & 1 & 3 & 6 & 5 & 5 & 5 & 7 \\
\hline Vietnam & 2 & 85.65 & 3 & 1 & 3 & 7 & 8 & 6 & 6 & 6 \\
\hline Indonesia & 3 & 82.69 & 1 & 2 & 4 & 2 & 1 & 9 & 8 & 9 \\
\hline Nepal & 4 & 77.42 & 1 & 2 & 4 & 1 & 2 & 8 & 4 & 8 \\
\hline Myanmar & 5 & 77.14 & 1 & 2 & 4 & 9 & 9 & 4 & 9 & 4 \\
\hline India & 6 & 65.19 & 2 & 3 & 1 & 5 & 4 & 7 & 2 & 5 \\
\hline Thailand & 7 & 59.9 & 3 & 1 & 3 & 8 & 3 & 2 & 7 & 3 \\
\hline Cambodia & 8 & 57.83 & 4 & 3 & 2 & 3 & 7 & 3 & 3 & 2 \\
\hline Malaysia & 9 & 32.24 & 2 & 3 & 1 & 4 & 6 & 1 & 1 & 1 \\
\hline
\end{tabular}

\section{References}

Behrman, J., Pollak, R., \& Taubman, P. (1982). Parental Preferences and Provision forProgeny. Journal of Political Economy, 90(1) 52-73. http://dx.doi.org/10.1086/261039

Bolt, K., Buys, P., Dasgupta, S., Hamilton, K., Meisner, C., Pandey, K., Wang, L., \& Wheeler, D. (2003). Measuring Up: New Directions for Environmental Programs at the World Bank. World Bank Policy Research Working Paper, 3097, July.

Buys, P., Chomitz, K., Dasgupta, S., Deichmann, U., Larsen, B., Meisner, C., ... Wheeler, D. (2004). The Economics of Regional Poverty-Environment Programs: An Application for Lao People's Democratic Republic. World Bank Policy Research Working Paper, 3267, April.

Dasgupta, S., Hammer, D., Kraft, R., \& Wheeler, D. (2012a). Vyāghranomics in Space and Time: Estimating Habitat Threats for Bengal, Indochinese, Malayan and Sumatran Tigers. World Bank Policy Research Working Paper, 6212, Washington, DC.

Dasgupta, S., Hammer, D., Kraft, R., \& Wheeler, D. (2012b). Forest Habitat Protection in Tropical Tiger Range Countries: Measuring Results Since 2007. Washington, DC: World Bank, Mimeo.

Hansen, M., DeFries, R., Townshend, J. R., Carroll, M., Dimiceli, C., \& Sohlberg, R. (2006). Vegetation Continuous Fields MOD44B, 2001 Percent Tree Cover, Collection 4. University of Maryland, College Park, Maryland, 2001.

Hansen, M., Stehman, S., Potapov, P., Loveland, T., Townshend, J., DeFries, R., ... Dimiceli, C. (2008). Humid tropical forest clearing from 2000 to 2005 quantified using multi-temporal and multi-resolution remotely sensed data. PNAS, 105(27), 9439-9444. http://dx.doi.org/10.1073/pnas.0804042105

Harrison, A. (2002). Has Globalization Eroded Labor's Share? Some Cross-Country Evidence. UC Berkeley and NBER.

Pandey, K., Ramankutty, R., Buys, P., Chomitz, K., \& Wheeler, D. (2005). Biodiversity Conservation Indicators: New Tools for Priority-Setting at the Global Environment Facility. GEF Working Paper. November.

Wheeler, D. (2011). Quantifying Vulnerability to Climate Change: Implications for Adaptation Assistance. 
Center for Global Development Working Paper 240. January.

\section{Appendix A}

Values for Ranked Variables

\begin{tabular}{|c|c|c|c|c|c|c|c|c|c|}
\hline Country & $\begin{array}{l}\text { Habitat Name } \\
\text { (Tiger Landscape) }\end{array}$ & $\begin{array}{l}\text { Subspecies } \\
\text { Numbers }\end{array}$ & $\begin{array}{l}\text { Subspecies } \\
\text { Distribution }\end{array}$ & $\begin{array}{l}\text { Subspecies } \\
\text { Habitat }\end{array}$ & $\begin{array}{l}\text { Habitat } \\
\text { Size }\end{array}$ & $\begin{array}{l}\text { Habitat } \\
\text { Percent } \\
\end{array}$ & $\begin{array}{l}\text { Land } \\
\text { Cost }\end{array}$ & $\begin{array}{l}\text { Labor } \\
\text { Cost }\end{array}$ & $\begin{array}{l}\text { Effective } \\
\text { Protection }\end{array}$ \\
\hline Cambodia & $\begin{array}{l}\text { Cambodian Northern } \\
\text { Plains }\end{array}$ & 0.10 & 1.14 & 11.32 & 26835 & 5.88 & 2.625 & 102.67 & 2.71 \\
\hline Cambodia & Cardamom's & 0.10 & 1.14 & 11.32 & 26345 & 97.29 & 2.711 & 102.67 & 2.71 \\
\hline India & Anamalai-Parambikulam & 0.67 & 0.84 & 18.48 & 3071 & 92.66 & 0.550 & 136.26 & 0.26 \\
\hline India & Bandhavgarh - Panpatha & 0.67 & 0.84 & 18.48 & 2020 & 4.99 & 0.010 & 136.26 & 0.26 \\
\hline India & Biligiri Range & 0.67 & 0.84 & 18.48 & 278 & 22.66 & 0.010 & 136.26 & 0.26 \\
\hline India & Chandoli & 0.67 & 0.84 & 18.48 & 1682 & 26.63 & 0.190 & 136.26 & 0.26 \\
\hline India & Corbett - Sonanadi & 0.67 & 0.84 & 18.48 & 5996 & 34.04 & 0.010 & 136.26 & 0.26 \\
\hline India & Dandeli - Anshi & 0.67 & 0.84 & 18.48 & 2316 & 99.99 & 0.010 & 136.26 & 0.26 \\
\hline India & Dandeli North & 0.67 & 0.84 & 18.48 & 517 & 99.49 & 0.010 & 136.26 & 0.26 \\
\hline India & Indravati & 0.67 & 0.84 & 18.48 & 44238 & 48.75 & 0.301 & 136.26 & 0.26 \\
\hline India & Kanha û Phen & 0.67 & 0.84 & 18.48 & 10598 & 45.01 & 0.010 & 136.26 & 0.26 \\
\hline India & Kaziranga - Garampani & 0.67 & 0.84 & 18.48 & 7514 & 85.09 & 0.074 & 136.26 & 0.26 \\
\hline India & $\begin{array}{l}\text { Mahabaleshwar } \\
\text { Landscape - South }\end{array}$ & 0.67 & 0.84 & 18.48 & 344 & 2.99 & 0.010 & 136.26 & 0.26 \\
\hline India & $\begin{array}{l}\text { Northern Forest Complex } \\
\text { - Namdapha - Royal } \\
\text { Manas }\end{array}$ & 0.67 & 0.84 & 18.48 & 237820 & 38.44 & 0.949 & 136.26 & 0.26 \\
\hline India & $\begin{array}{l}\text { Pachmarhi - Satpura - } \\
\text { Bori }\end{array}$ & 0.67 & 0.84 & 18.48 & 4924 & 16.41 & 0.010 & 136.26 & 0.26 \\
\hline India & Palamau & 0.67 & 0.84 & 18.48 & 3209 & 11.99 & 0.010 & 136.26 & 0.26 \\
\hline India & Pench & 0.67 & 0.84 & 18.48 & 2918 & 16.68 & 0.010 & 136.26 & 0.26 \\
\hline India & Periyar - Megamala & 0.67 & 0.84 & 18.48 & 5978 & 84.10 & 0.161 & 136.26 & 0.26 \\
\hline India & Purna & 0.67 & 0.84 & 18.48 & 1002 & 5.16 & 0.010 & 136.26 & 0.26 \\
\hline India & Radhanagari & 0.67 & 0.84 & 18.48 & 2945 & 32.75 & 0.151 & 136.26 & 0.26 \\
\hline India & Rajaji Major & 0.67 & 0.84 & 18.48 & 322 & 17.24 & 0.010 & 136.26 & 0.26 \\
\hline India & Rajaji Minor & 0.67 & 0.84 & 18.48 & 1044 & 64.99 & 0.010 & 136.26 & 0.26 \\
\hline India & Royal Bardia & 0.67 & 0.84 & 18.48 & 6777 & 61.74 & 0.257 & 136.26 & 0.26 \\
\hline India & Royal Chitwan & 0.67 & 0.84 & 18.48 & 4055 & 65.61 & 0.010 & 136.26 & 0.26 \\
\hline India & Royal Suklaphanta & 0.67 & 0.84 & 18.48 & 1144 & 0.99 & 0.010 & 136.26 & 0.26 \\
\hline India & Satkosia-Gorge & 0.67 & 0.84 & 18.48 & 2699 & 55.44 & 0.839 & 136.26 & 0.26 \\
\hline India & Shendurney & 0.67 & 0.84 & 18.48 & 603 & 99.40 & 0.604 & 136.26 & 0.26 \\
\hline India & Simlipal & 0.67 & 0.84 & 18.48 & 2412 & 89.66 & 0.010 & 136.26 & 0.26 \\
\hline India & Sunabeda-Udanti & 0.67 & 0.84 & 18.48 & 2287 & 14.09 & 0.010 & 136.26 & 0.26 \\
\hline India & $\begin{array}{l}\text { Western Ghats - } \\
\text { Sharavathi Valley }\end{array}$ & 0.67 & 0.84 & 18.48 & 321 & 99.99 & 0.010 & 136.26 & 0.26 \\
\hline India & $\begin{array}{l}\text { Western Ghats: Bandipur } \\
\text { - Khudrenukh û Bhadra }\end{array}$ & 0.67 & 0.84 & 18.48 & 18973 & 75.16 & 0.073 & 136.26 & 0.26 \\
\hline Indonesia & Berbak & 0.09 & 0.00 & 9.32 & 2543 & 94.28 & 4.034 & 158.81 & 4.91 \\
\hline Indonesia & $\begin{array}{l}\text { Bukit BalaiRejang - } \\
\text { Selatan }\end{array}$ & 0.09 & 0.00 & 9.32 & 3884 & 99.78 & 0.221 & 158.81 & 4.91 \\
\hline Indonesia & $\begin{array}{l}\text { Bukit Barisan Selatan } \\
\text { South }\end{array}$ & 0.09 & 0.00 & 9.32 & 2107 & 99.77 & 0.228 & 158.81 & 4.91 \\
\hline Indonesia & Bukit Barisan South & 0.09 & 0.00 & 9.32 & 2890 & 97.76 & 2.236 & 158.81 & 4.91 \\
\hline Indonesia & Bukit Rimbang Baling & 0.09 & 0.00 & 9.32 & 4395 & 97.38 & 2.623 & 158.81 & 4.91 \\
\hline Indonesia & $\begin{array}{l}\text { Bukit Tigapuluh } \\
\text { Landscape }\end{array}$ & 0.09 & 0.00 & 9.32 & 7106 & 67.22 & 4.475 & 158.81 & 4.91 \\
\hline Indonesia & GunugLeuser & 0.09 & 0.00 & 9.32 & 22319 & 99.29 & 0.709 & 158.81 & 4.91 \\
\hline Indonesia & KerinciSeblat & 0.09 & 0.00 & 9.32 & 28162 & 97.86 & 2.142 & 158.81 & 4.91 \\
\hline
\end{tabular}




\begin{tabular}{|c|c|c|c|c|c|c|c|c|c|}
\hline Indonesia & Kualar & 0.09 & 0.00 & 9.32 & 9835 & 62.35 & 19.775 & 158.81 & 4.91 \\
\hline & Kampar-Kerumutan & & & & & & & & \\
\hline \multirow[t]{2}{*}{ Indonesia } & RimboPanti-BatangGadis & 0.09 & 0.00 & 9.32 & 1486 & 99.89 & 0.109 & 158.81 & 4.91 \\
\hline & West & & & & & & & & \\
\hline Indonesia & Sibologa & 0.09 & 0.00 & 9.32 & 1292 & 99.67 & 0.334 & 158.81 & 4.91 \\
\hline Indonesia & TessoNilo Landscape & 0.09 & 0.00 & 9.32 & 2332 & 56.49 & 43.514 & 158.81 & 4.91 \\
\hline Laos & Hin Nam Ho & 0.10 & 1.14 & 11.32 & 2727 & 98.30 & 1.701 & 111.88 & 1.59 \\
\hline Laos & Nam Et PhouLoey & 0.10 & 1.14 & 11.32 & 17866 & 99.25 & 0.750 & 111.88 & 1.59 \\
\hline Laos & Nam Ha & 0.10 & 1.14 & 11.32 & 3217 & 99.43 & 0.568 & 111.88 & 1.59 \\
\hline Laos & Northern Annamites & 0.10 & 1.14 & 11.32 & 28826 & 97.47 & 2.525 & 111.88 & 1.59 \\
\hline Laos & PhuMiang - Phu Thong & 0.10 & 1.14 & 11.32 & 16273 & 65.99 & 0.010 & 111.88 & 1.59 \\
\hline Laos & Southern Annamites & 0.10 & 1.14 & 11.32 & 61252 & 98.92 & 0.339 & 111.88 & 1.59 \\
\hline Malaysia & Endau Rompin & 0.14 & 0.00 & 6.14 & 6505 & 86.55 & 13.451 & 325.28 & 6.72 \\
\hline Malaysia & Krau & 0.14 & 0.00 & 6.14 & 1248 & 94.25 & 5.754 & 325.28 & 6.72 \\
\hline Malaysia & Taman Negara - Belum & 0.14 & 0.00 & 6.14 & 49181 & 94.16 & 5.835 & 325.28 & 6.72 \\
\hline \multirow[t]{3}{*}{ Myanmar } & Northern Forest Complex & 0.67 & 0.84 & 18.48 & 237820 & 99.60 & 0.402 & 74.08 & 2.07 \\
\hline & - Namdapha - Royal & & & & & & & & \\
\hline & Manas & & & & & & & & \\
\hline Myanmar & Tenasserims & 0.67 & 0.84 & 18.48 & 162726 & 96.65 & 3.351 & 74.08 & 2.07 \\
\hline Nepal & Corbett - Sonanadi & 0.67 & 0.84 & 18.48 & 5996 & 36.99 & 0.010 & 74.84 & 0.07 \\
\hline Nepal & Royal Bardia & 0.67 & 0.84 & 18.48 & 6777 & 63.70 & 0.078 & 74.84 & 0.07 \\
\hline Nepal & Royal Bardia South & 0.67 & 0.84 & 18.48 & 499 & 45.99 & 0.208 & 74.84 & 0.07 \\
\hline Nepal & Royal Chitwan & 0.67 & 0.84 & 18.48 & 4055 & 61.72 & 0.010 & 74.84 & 0.07 \\
\hline Nepal & Royal Suklaphanta & 0.67 & 0.84 & 18.48 & 1144 & 49.99 & 0.010 & 74.84 & 0.07 \\
\hline Thailand & Cardamom's & 0.10 & 1.14 & 11.32 & 26345 & 65.26 & 0.638 & 245.08 & 1.94 \\
\hline Thailand & KhaoYai & 0.10 & 1.14 & 11.32 & 2253 & 9.16 & 0.010 & 245.08 & 1.94 \\
\hline Thailand & KhlongSaeng & 0.14 & 0.00 & 6.14 & 4816 & 99.46 & 0.536 & 245.08 & 1.94 \\
\hline Thailand & PhuKhieo & 0.10 & 1.14 & 11.32 & 5760 & 76.25 & 0.327 & 245.08 & 1.94 \\
\hline Thailand & PhuMiang - Phu Thong & 0.10 & 1.14 & 11.32 & 16273 & 64.57 & 0.763 & 245.08 & 1.94 \\
\hline Thailand & Salak-Phra & 0.10 & 1.14 & 11.32 & 647 & 74.85 & 0.579 & 245.08 & 1.94 \\
\hline Thailand & Taman Negara - Belum & 0.14 & 0.00 & 6.14 & 49181 & 99.42 & 0.577 & 245.08 & 1.94 \\
\hline Thailand & Tenasserims & 0.10 & 1.14 & 11.32 & 162726 & 85.95 & 2.600 & 245.08 & 1.94 \\
\hline Thailand & ThapLan - Pang Sida & 0.10 & 1.14 & 11.32 & 4445 & 0.99 & 0.010 & 245.08 & 1.94 \\
\hline Vietnam & Bi Dup-Nui Ba & 0.10 & 1.14 & 11.32 & 1660 & 98.97 & 1.030 & 129.77 & 0.72 \\
\hline Vietnam & Cat Tien & 0.10 & 1.14 & 11.32 & 3359 & 35.50 & 1.505 & 129.77 & 0.72 \\
\hline Vietnam & KonKaKinh & 0.10 & 1.14 & 11.32 & 6389 & 93.75 & 0.349 & 129.77 & 0.72 \\
\hline Vietnam & Nam Et PhouLoey & 0.10 & 1.14 & 11.32 & 17866 & 35.05 & 1.077 & 129.77 & 0.72 \\
\hline Vietnam & Northern Annamites & 0.10 & 1.14 & 11.32 & 28826 & 99.49 & 0.508 & 129.77 & 0.72 \\
\hline Vietnam & Southern Annamites & 0.10 & 1.14 & 11.32 & 61252 & 95.18 & 0.493 & 129.77 & 0.72 \\
\hline
\end{tabular}

\section{Copyrights}

Copyright for this article is retained by the author(s), with first publication rights granted to the journal.

This is an open-access article distributed under the terms and conditions of the Creative Commons Attribution license (http://creativecommons.org/licenses/by/3.0/). 